\title{
Non-Thermal Process: Ultrasonic Applications in Dairy Industry
}

\author{
AK Agrawal*, Banavath Prasanth, M Dharani, T Arvind and Krishan Dewangan \\ Department of Dairy Engineering, College of Dairy Science and Food Technology, India
}

Submission: January 25, 2018; Published: March 19, 2018

"Corresponding author: AK Agrawal, Department of Dairy Engineering, College of Dairy Science and Food Technology, Raipur, India, Email: akagrawal.raipur@gmail.com

\section{Opinion}

Conventional method heat treatment is the most widely method used to achieve preservation of food, but heat can also have a negative impact on nutritive value and organoleptic properties of foods. The conventional method of milk processing used thermal treatment, such as pasteurization and ultrahigh temperature (UHT). When existing methods of pasteurization and ultrahigh temperatures are used, the drawback of these methods is lowering of organoleptic and nutritional quality [1]. For this reason, Ultrasound can be used as an alternative method to inactivate enzymes and destroy microorganisms with little or no heat.

Ultrasonic is a high power sound wave at frequencies between $16 \mathrm{kHz}$ and $100 \mathrm{MHz}$ [2]. The major advantage of ultrasound to conventional dairy processes has the potential to provide significant benefits for the dairy industry such as energy savings and improved product properties and non-thermal preserving the food. Ultrasonic process provokes the destruction of bacteria by cavitation bubbles caused by pressure different. During ultrasonication process, the sound wave encounters a liquid medium creating longitudinal waves, that generates regions of low pressure. These regions of different pressure cause cavitation and gas bubble formation. These bubbles increase gradually their volume until they implode, creating regions of high temperature and pressure. The pressure resulting from these implosions cause the main bactericidal effect of ultrasonics.

Ultrasonic is a considered to be an emerging technology in the dairy industry. Ultrasonic is considered as an alternative method for reducing fat globules size and can be effectively applied in place of conventional homogenizer. Consequently, ultrasonic is a good alternative method for food processing and preservation. Power (High-frequency) ultrasounds are used for specific dairy processing applications such as homogenization, crystallization, drying, and non- thermal sterilization or pasteurization.

In the food industry the use of ultrasound is divided into two categories: low-intensity $(\mathrm{kHz})$ and high-intensity $(\mathrm{MHz})$ ultrasound. The low-intensity ultrasound $\left(<20 \mathrm{kHz}, 1 \frac{w}{\mathrm{~cm}^{2}}\right.$ lower then range) is a non-destructive technique providing information about physicochemical properties of food highintensity ultrasound ( $>20 \mathrm{kHz}, \frac{1}{\mathrm{~cm}^{2}}$ higher then range) is used to modify and alter food.

Ultrasonic at a low temperature is not severe enough for sufficient destruction of microbes. Some of the investigations shown that ultrasonic in combination with temperature has accelerate rate for the sterilization of food [3]. To improve the microbial destruction, ultrasonic is combined with treatments such as pressure, heat and both pressure and heat.

\section{Thermosonication (TS)}

The combination of heat and high power ultrasonic (thermoultrasonication) was first explored by Ordonez et al. [3]. The thermosonication combines moderate heat $\left(37\right.$ to $\left.75^{\circ} \mathrm{C}\right)$ with ultrasonic treatment.

\section{Manosonication (MS)}

It combines the ultrasonic with moderate pressure (100 $-300 \mathrm{kPa}$ ) at sub lethal temperature. In 1992, Sala et al. [4] designed and built a resistometer to apply high-power ultrasonic under pressure at nonlethal and lethal temperatures. Results obtained with this instrument demonstrated that the rate of vegetative-cell inactivation by manosonication increased drastically when the static pressure was raised. The inactivation of microorganisms by ultrasonic waves was reported in the early 1930s [5].

\section{Manothermosonication (MTS)}

Manothermosonication consists of the simultaneous application of heat and ultrasound under moderate pressure $(100-700 \mathrm{kPa})$. It is one of these new technologies [6]. Manothermosonication is an efficient tool to inactivate enzymes and bacteria in milk. Moreover, ultrasonic is an as a safe processing technique compared to other emerging technologies [7]. 


\section{References}

1. Chemat F, Khan MK (2011) Applications of ultrasound in food technology: processing, preservation and extraction. Ultrasonics sonochemistry 18(4): 813-835.

2. Ugarte-Romero E, Feng $H$, Martin SE (2007) Inactivation of Shigella boydii 18 IDPH and Listeria monocytogenes Scott A with power ultrasound at different acoustic energy densities and temperatures. Journal of food science 72(4): M103-107.

3. Ordoñez JA, Aguilera MA, Garcia ML, Sanz B (1987) Effect of combined ultrasonic and heat treatment (thermoultrasonication) on the survival of a strain of Staphylococcus aureus. Journal of Dairy Research 54(1): 61-67.

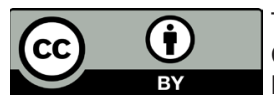

4. Sala FJ, Burgos J, Condón S, López P, Raso J, et al. (1992) Procedimiento para la destrucción de microorganismos y enzimas: proceso MTS. Spanish patent 93: 00021.

5. Harvey EN, Loomis AL (1929) The destruction of luminous bacteria by high frequency sound waves. Journal of Bacteriology 17(5): 373-376.

6. Lopez P, Sala, FJ, de la Fuente JL, Condon S, Raso J, et al. (1994) Inactivation of peroxidase, lipoxygenase, and polyphenol oxidase by manothermosonication. Journal of Agricultural and Food Chemistry 42(2): 252-256.

7. Mahdi Jafari S, He Y, Bhandari B (2006) Nano-emulsion production by sonication and microfluidization-a comparison. International Journal of Food Properties 9(3): 475-485.

\begin{tabular}{l} 
Your next submission with Juniper Publishers \\
will reach you the below assets \\
- Quality Editorial service \\
- Swift Peer Review \\
- Reprints availability \\
- E-prints Service \\
- Manuscript Podcast for convenient understanding \\
- Global attainment for your research \\
- Manuscript accessibility in different formats \\
( Pdf, E-pub, Full Text, Audio) \\
- Unceasing customer service \\
Track the below URL for one-step submission \\
https://juniperpublishers.com/online-submission.php \\
\hline
\end{tabular}

